\title{
O (ZERO)
}

\section{0 (ZERO)}

Letícia Rodrigues $^{1}$

Resumo: 0 (zero) $^{2}$ é uma dança desenvolvida na tessitura entre fragilidade, erro, limite e respiração. O espetáculo surge de questões autobiográficas como motor das corporeidades: zerar para entender o que move e o que é movido. Dessa escuta, cria-se um espaço pneumático que se constitui como um organismo único através do diálogo entre corpo, objeto-corpo e música - tríade que compõe o espetáculo. 0 é um processo atemporal.

Há pouco mais de dez anos descobri que possuía uma condição genética que limitava (?) ${ }^{3}$ minha materialidade: a Síndrome da Hipermobilidade Benigna ou frouxidão ligamentar. 0 (zero) faz emergir sentimentos como dor, desesperança e pessimismo como forma de potência buscando caminhos de fuga e cartografias de (des)ordem do corpo como pesquisa de movimento.

Como início para a criação, estudei a ontogênese, como se fosse uma viagem no tempo, a fim de encontrar em qual momento se deu o erro ${ }^{4}$. Assim, encontrei uma imagem de um feto, com quatro semanas, flutuando em sua bolsa amniótica, com o coração aparentemente muito acelerado. Era o começo de tudo. Da imagem, busquei como construir a atmosfera da bolsa amniótica, a respiração acelerada e o movimento de flutuar.

Para a criação da bolsa, após muita pesquisa, encontrei artistas e arquitetos dos anos 60 e 70 que trabalharam com estruturas ou objetos infláveis como, a Ant Farm e Michael Webb, que me ajudaram a construir o objeto que compõem a estrutura coreográfica, cênica e poética de 0 (zero). Utilizei como material o plástico bolha por diversos motivos: devido ao seu baixo custo; por sua leveza e, consequentemente, por sua maleabilidade nas construções de esculturas de ar; e pela própria sonoridade do material em si e de suas pequenas bolhas que, ao serem estouradas, me remeteram aos mesmos sons produzidos pelos estalos do meu corpo.

Enquanto pesquisa, o movimento transitou entre um tempo dilatado a um tempo rápido, explorando nos caminhos do nível baixo ao nível alto, um corpo bloqueado ou contorcido, onde micro e macro movimentos articulares, tensões musculoesqueléticas, peso e respiração eram convocados para o aparecimento de algo ainda por devir no visível.

A artista da dança Beatriz Sano, que fez a provocação do espetáculo, teve grande colaboração na pesquisa de movimento e me fez encontrar caminhos para um movimento lento, suave, espiralado e que contribuiu para criar a ilusão de flutuar e de esculpir o ar sem o uso do objeto-corpo. Durante algumas pesquisas encontrei uma segunda imagem que me identifiquei e que me ajudou a visualizar essa movimentação lenta de corpo aparentemente frágil: o pepino do mar caminha dois centímetros por minutos nas profundezas marítimas.

0 (zero) é um espetáculo solo criado cuidadosamente com a colaboração de muitas pessoas, desde as que participaram diretamente do projeto, como as que participaram indiretamente no ensaio aberto, por exemplo. Umas dessas colaborações é a do compositor e músico Gustavo Infante que realizou a composição musical para a dança, da execução de tal composição ao vivo em todas as apresentações e da colaboração na construção do objeto-

\footnotetext{
${ }^{1}$ Artista independente, Campinas, SP, Brasil.

2 Este espetáculo recebeu o VII Prêmio Denilto Gomes de Dança 2019 na categoria "Revelação" e o ProAC Produção de Espetáculo Inédito e Temporada de Dança (2018).

${ }^{3} \mathrm{O}$ processo de criação questionou o que é o limite para o corpo que dança.

${ }^{4}$ A Síndrome da Hipermobilidade Benigna ou frouxidão ligamentar é uma condição genética de erro na produção de colágeno.
} 
corpo presente na cena ${ }^{5}$. A música é um corpo invisível presente na cena que ajuda a produzir os sentidos do espetáculo. A música criada por Gustavo gerou outra atmosfera e é possível afirmar que o espetáculo é constituído por um trio inseparável e em uníssono: corpo, objeto-corpo e música.

Outra colaboração importante para a criação de 0 (zero) é da figurinista Marjoly Lino. Para o figurino, Marjoly recriou uma camisa, peça que pertenceu à minha avó materna. Assim, trago em 0 (zero), parte da minha genética materializada e que contribui para a construção da narrativa atemporal de células, genes e líquido amniótico.

Uma videodança foi criada como parte integrante do espetáculo, com a participação especial da artista da dança Gabriela Branco e edição de Esther Lourenço. Para a criação da videodança criamos diferentes esferas espaço-temporais onde partes do corpo, principalmente as articulações, desapareciam no espaço para criar um corpo-máquina (im)perfeito.

Uma oficina e uma residência artística fizeram parte do projeto e modificaram meus anseios futuros para com esse espetáculo e para o que concebo hoje como dança contemporânea. A residência, com cinco dias de duração, contou com a presença de onze participantes (atores, artistas da dança e interessados na arte em geral) e resultou em uma performance no hall do Sesc Campinas. No dia, ventava muito e, por mais que tentávamos fechar as portas impedindo a corrente do ar, os objetos-corpo possuíam seus próprios movimentos que foram belamente orquestrando os corpos dos participantes, ao mesmo tempo em que eram orquestrados. Isso demonstra que, no processo de criação e na obra de arte em si, não há erro. Não há limite para o corpo que dança. Há a exploração estética de rupturas que abrem espaços para novas modelagens.

Por fim, encerro esse ensaio com uma frase de Laurence Louppe, material muito usado na criação de 0 (zero), como reflexão sobre o projeto contemporâneo da dança: “[...] a descoberta de um corpo que encerra um modo singular de simbolização, alheio a qualquer modelo preconcebido." (LOUPPE, 2012, p. 62)

\section{Ficha técnica}

Letícia Rodrigues - dança e concepção geral

Beatriz Sano - provocação

Gustavo Infante - composição e música ao vivo

Gabriela Branco - dança (part. especial videodança)

Rossana Boccia - desenho e operação de luz

InCápsula - projeção ao vivo

Marjoly Lino - figurinista

Bufa Produções (Aline Grisa) - produção executiva

wrzaratini - fotos e captação imagens videodança

Esther Lourenço - edição videodança

Elisa Carareto - projeto gráfico

Bruta Flor Filmes - registro videográfico

Nossa Senhora da Pauta - assessoria de imprensa

Duração: 50 minutos

Classificação etária: 12 anos

\footnotetext{
${ }^{5}$ Foram construídos quatro objetos-corpo ao longo das apresentações. Cada objeto demora, em média, três horas para ser construído.

${ }^{6}$ LOUPPE, Laurence. Poética da dança contemporânea. Tradução de Rute Alves Pereira e Costa; Prefácio de Maria José Fazenda. Lisboa: Orfeu Negro, 2012. 400 p.
} 
0 (ZERO)

Link teaser: https://www.youtube.com/watch?v=8nK70rpNwBg

Link videodança: https://www.youtube.com/watch?v=0z9PeDMxKNg
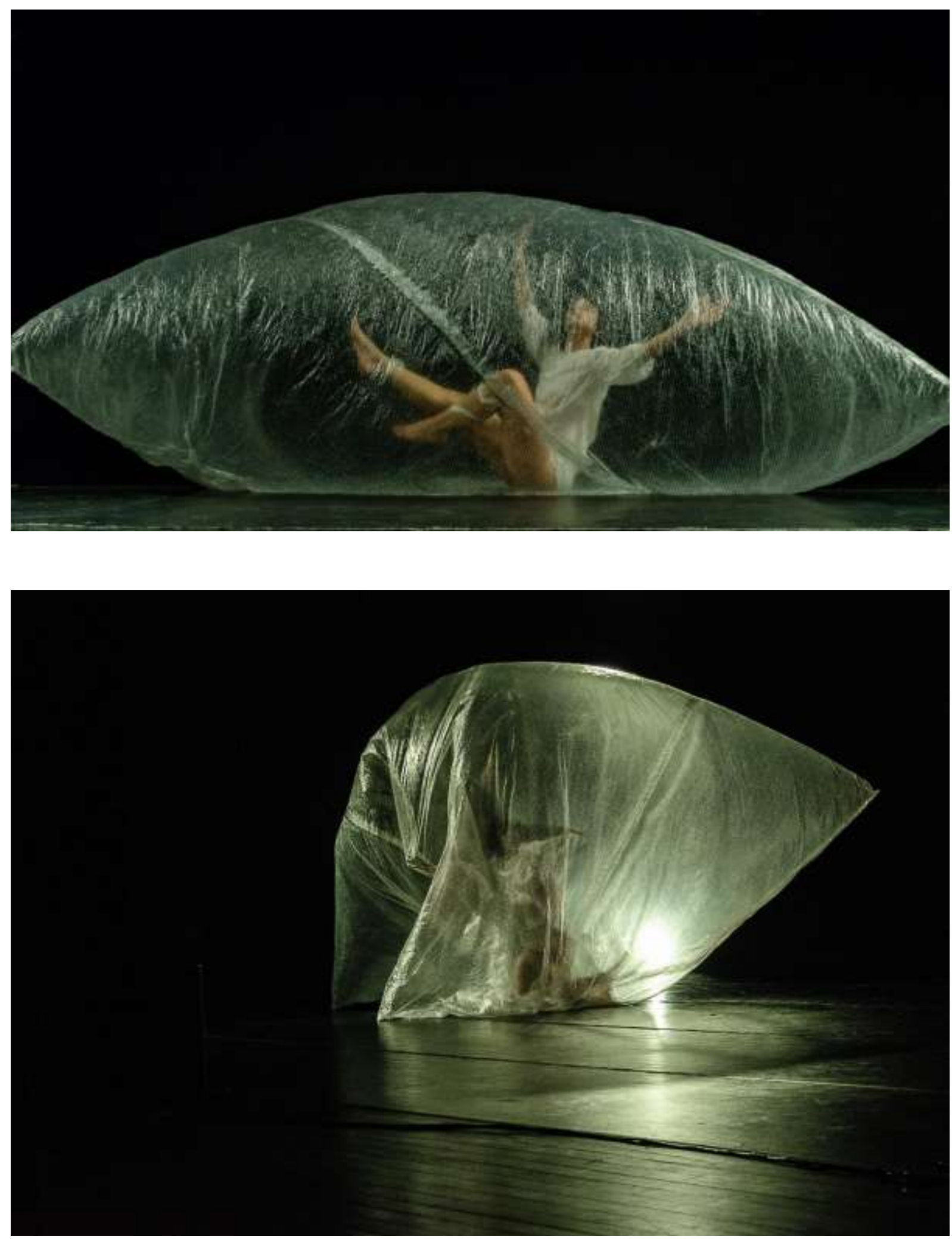

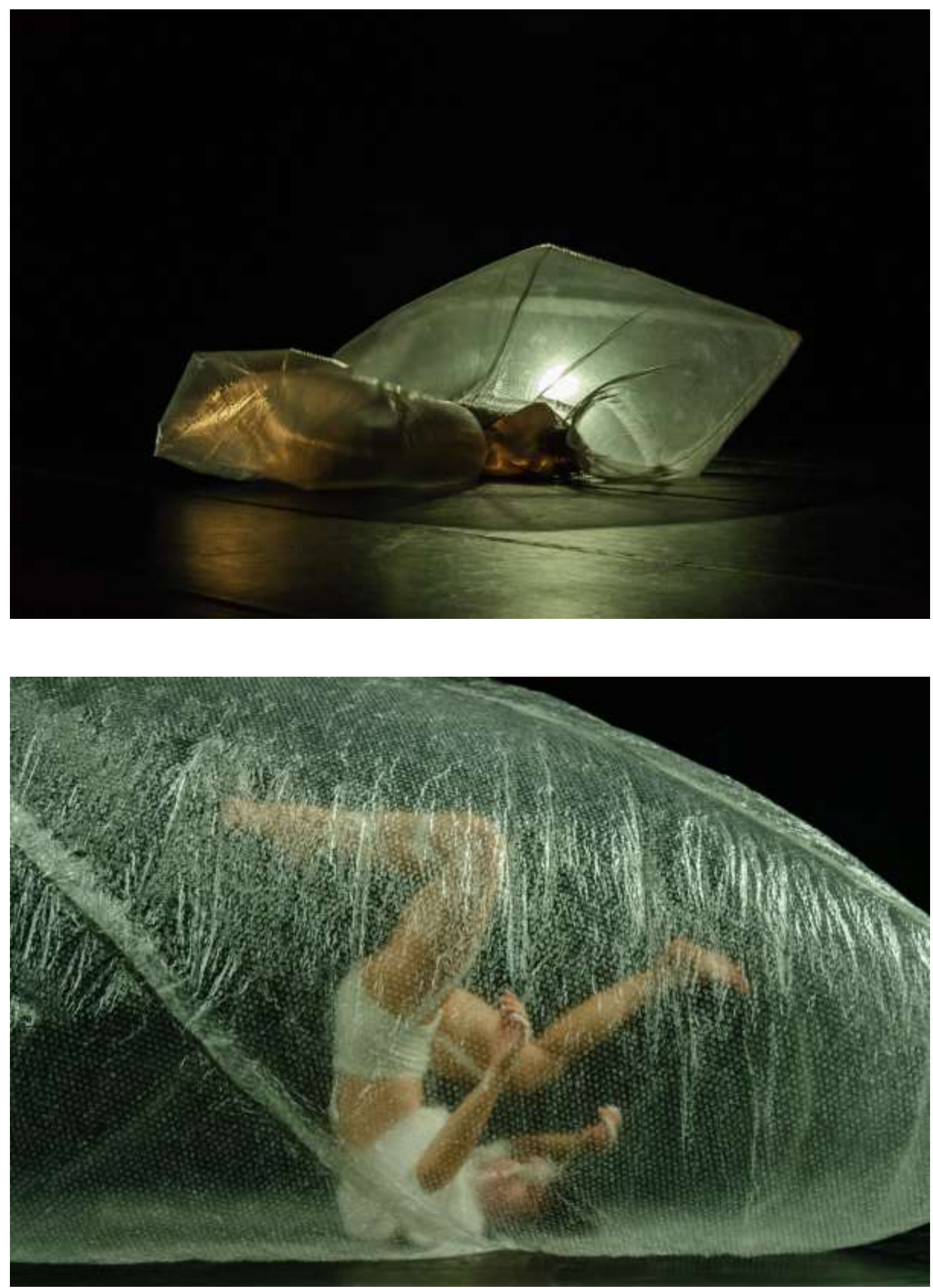
0 (ZERO)
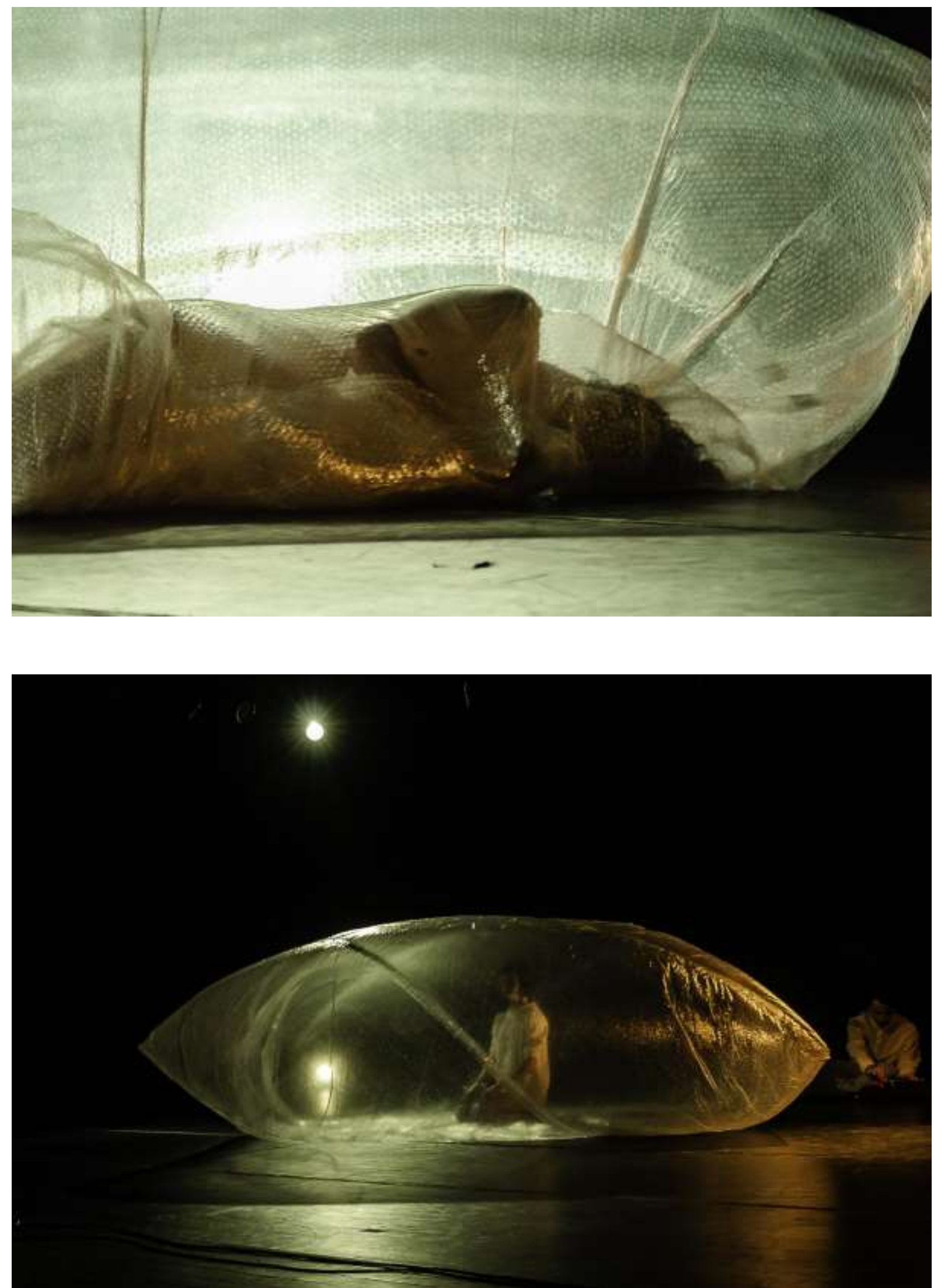

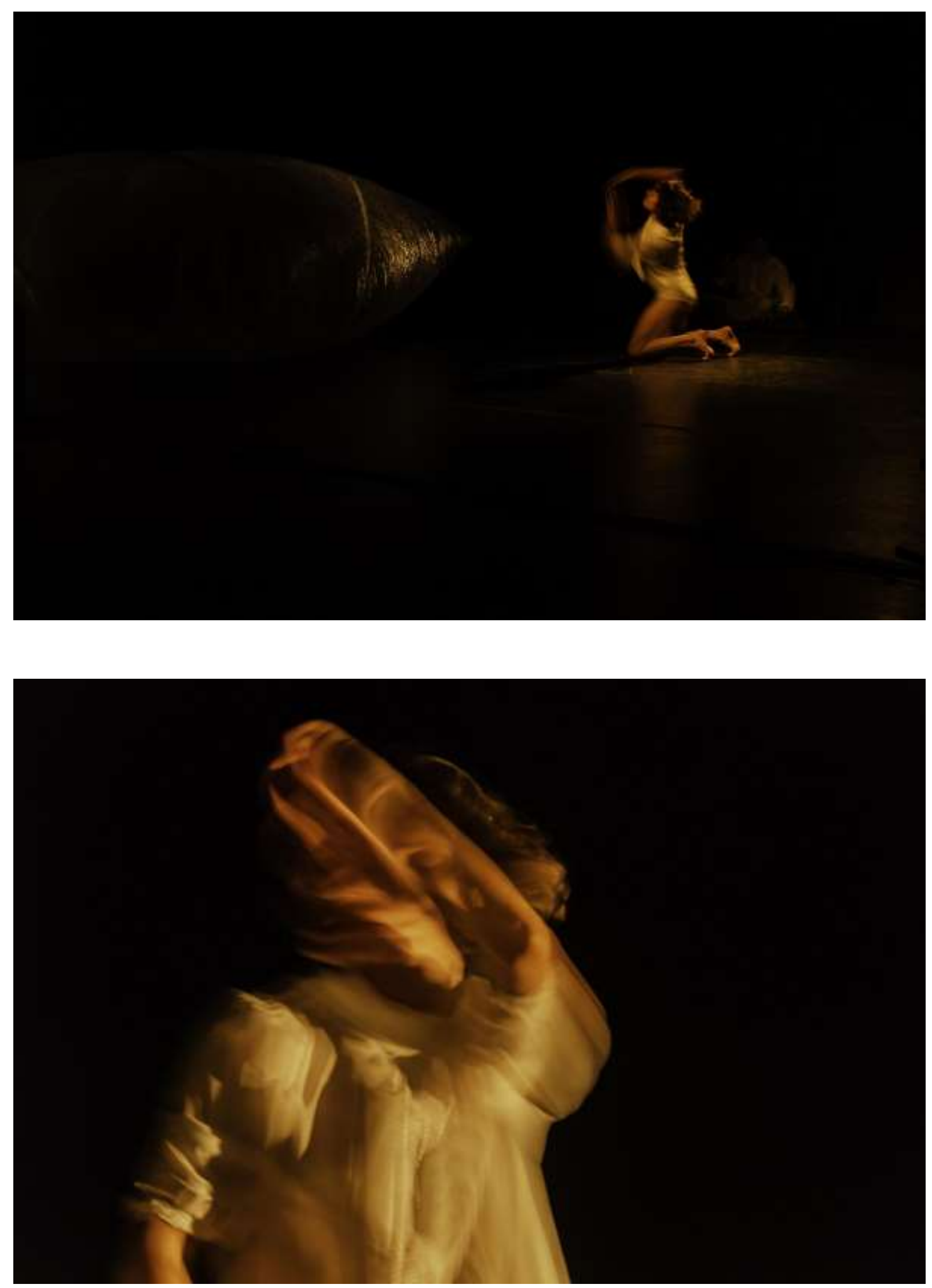


\section{Sobre a autora}

Letícia Rodrigues. Artista da dança e professora. Mestra em Educação (UNICAMP), Bacharel e Licenciada em Dança (UNICAMP). Em 2019, estreou o espetáculo 0 (zero) contemplado pelo Prêmio ProAC Produção de Espetáculo Inédito e Temporada de Dança e, com esse espetáculo, recebeu o VII Prêmio Denilto Gomes de Dança na categoria "Revelação". Explora as possibilidades da dança, do corpo e do movimento em improvisações em dança, videodanças e fotoperformances, em um diálogo estreito com as artes visuais e a música. Tem parceria com o cantor, violonista e compositor Gustavo Infante em trabalhos de dança e criação e produção de videoartes e videoclipes. E-mail: orleticia@gmail.com. 